\title{
Goal conditioning throw mutimodal categorisation in a simulation of rat navigation
}

\author{
Souheïl Hanoune ${ }^{1 *}$, Mathias Quoy ${ }^{1,2}$, Philippe Gaussier ${ }^{1,2}$ \\ From Twenty Second Annual Computational Neuroscience Meeting: CNS*2013 \\ Paris, France. 13-18 July 2013
}

Navigation tasks are based on two approaches: placeaction directed or goal directed. In the goal directed ones, a reward is generally given to the system when the goal is reached. Many models are able to predict the reward in a simple cases. In this paper, we present an architecture for complex conditioning.

The purpose is to present a case where an association is used to predict the reward in the task. In this task, the goal is multimodal, i.e. the presence of one of the components is no longer sufficient. To correctly predict the reward, the correlation between two informations has to be saved. The experiment presents how the system can resolve ambiguities.

The hypothesis in our model is that when a hippocampal conditioning is failing, the prefrontal cortex is neuromodulated to facilitates the categorization of multimodal contexts. The goal is to encode the correlations between the inputs. When the contexts are activated in the future, they will help the conditioning in the hippocampus. The experimental setup is derived from the continuous place navigation task $[1,2]$, where a rat has to find a goal marked by a blue spot, then wait $0.3 \mathrm{~s}$ in this location in order to obtain the reward (food). An automated pellet giver producing a sound releases the food. After some time, the sound is linked to the food reward. In the experiment an ambiguity subsists between two locations: two blue spots are present in the environment but only one of them has the sound occurrence. The prediction of the reward is correlated with the correct prediction of the sound, in the sequence place-cell $\rightarrow$ blue spot $\rightarrow$ sound $\rightarrow$ food. In this work, we study how failure in the conditioning can be solved by introducing multimodal contexts.

\section{Author details \\ 'University of Cergy Pontoise, France. ${ }^{2}$ ETIS Laboratory, UMR 8051, ENSEA - University of Cergy-Pontoise, CNRS, France.}

Published: 8 July 2013
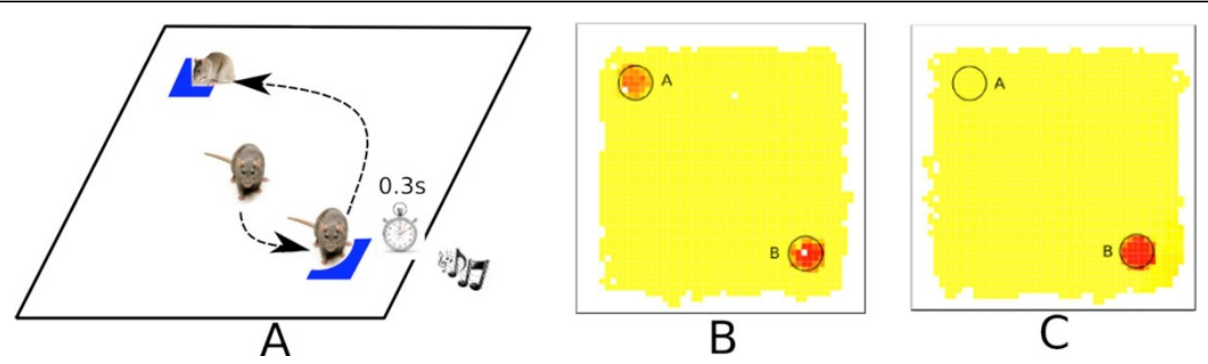

Figure 1 Panel A presents the experiment. There are two blue spots in the environment, but the reward is obtained by waiting $0.3 \mathrm{~s}$ in only one of them. Panel $B$ presents the reward predictions of the rat at the beginning: both of the spots are predicted as a reward. In panel $C$ that the reward is fully encoded in the place B and A is no longer predicted as a reward.

* Correspondence: souheil.hanoune@ensea.fr

'University of Cergy Pontoise, France

Full list of author information is available at the end of the article 


\section{References}

1. Hok V, Lenck-Santini P-P, Save E, Gaussier P, Banquet J-P, Poucet B: A test of the time estimation hypothesis of place cell goal-related activity. Journal of Integrative Neuroscience 2007, 6(3):367-378.

2. Hok V, Lenck-Santini P-P, Save, Roux S, Save E, Muller RU, Poucet B: Goalrelated activity in hippocampal place cells. Journal of Integrative Neuroscience 2007, 27(3):472-482.

doi:10.1186/1471-2202-14-S1-P137

Cite this article as: Hanoune et al: Goal conditioning throw mutimodal categorisation in a simulation of rat navigation. BMC Neuroscience 2013 14(Suppl 1):P137.

Submit your next manuscript to BioMed Central and take full advantage of:

- Convenient online submission

- Thorough peer review

- No space constraints or color figure charges

- Immediate publication on acceptance

- Inclusion in PubMed, CAS, Scopus and Google Scholar

- Research which is freely available for redistribution 